\title{
Application of supported lanthanum catalysts in the hydrogenation of nitriles
}

\author{
Kinga Juhász ${ }^{1}$ - Krisztina Lévay ${ }^{1}$ - László Hegedűs ${ }^{1}$ • Diána Balogh-Weiser ${ }^{1,2}$. \\ Laurence Pirault-Roy ${ }^{3} \cdot$ Zoltán Hell $^{1}$
}

Received: 7 June 2021 / Accepted: 16 July 2021 / Published online: 29 July 2021

(c) The Author(s) 2021

\begin{abstract}
Nickel and lanthanum on $\mathrm{MgO}$ or $\mathrm{MgO}-\mathrm{Al}_{2} \mathrm{O}_{3}$ catalysts were prepared and characterized. The applicability of the catalysts was studied in the liquid-phase hydrogenation of benzonitrile. A $\mathrm{La} / \mathrm{MgO}$ catalyst showed surprisingly high activity and selectivity. The scope of the reaction was extended to other nitriles (benzyl cyanide, cinnamonitrile, adiponitrile) over this $\mathrm{La} / \mathrm{MgO}$ catalyst.
\end{abstract}

Keywords Heterogeneous catalysis · Hydrogenation · Lanthanum · Magnesium oxide $\cdot$ Nitriles

JEL Classification codes O33 Technological change - Choices and consequences · Diffusion processes

\section{Introduction}

Heterogeneous catalysis is a widely researched field in organic chemistry. About $85-90 \%$ of all chemical manufacturing processes require the use of a catalyst. Among these reactions about $80-85 \%$ applies heterogeneous catalysis [1]. Therefore, the elaboration of new heterogeneous catalytic methods is of great importance in synthetic organic chemistry.

Primary amines represent an important group of intermediates and are widely used in the pharmaceutical and herbicide industry. There are various methods for

Zoltán Hell

hell.zoltan@vbk.bme.hu

1 Department of Organic Chemistry and Technology, Budapest University of Technology

and Economics, Múegyetem rkp. 3, Budapest 1111, Hungary

2 Department of Physical Chemistry and Materials Science, Budapest University of Technology and Economics, Múegyetem rkp. 3, Budapest 1111, Hungary

3 Institute of Chemistry of Poitiers: Materials and Natural Resources (IC2MP) UMR-CNRS 7285, University of Poitiers, 4 Rue Michel Brunet (Bât B27), 86073 Poitiers Cedex, France 
their synthesis, such as the alkylation of ammonia and the reductive amination of oxo compounds. However, a frequently used preparation method in the pharmaceutical industry is the heterogeneous catalytic hydrogenation of nitriles [2].

Benzylamine is an important intermediate for the synthesis of several drugs [3], dyes or synthetic resins [2]. Another application is as a corrosion inhibitor [4]. In the asymmetric hydrogenation of $\alpha, \beta$-unsaturated carboxylic acids over cinchonidinemodified $5 \% \mathrm{Pt} / \mathrm{Al}_{2} \mathrm{O}_{3}$ catalyst, benzylamine is used as an additive to enhance the enantioselectivity [5].

It is well-known, that during the conversion of nitriles into primary amines secondary and tertiary amines can be formed in side reactions decreasing the selectivity of the reaction [6-10]. The amount of the secondary and tertiary amines in the reaction mixture can be minimized by the removal of the primary amine [11-16] or by the addition of excess ammonia [17-20]. Usually a Raney® nickel [17, 19, 20] or rhodium catalyst [18] is required to achieve high primary amine selectivity. However, more and more methods have been elaborated for the selective hydrogenation of benzonitriles using nickel [21-23] ruthenium [24-26] and palladium [27-31] catalysts.

Although lanthanum was used in the heterogeneous catalytic hydrogenation of olefinic double bonds [32], p-chloronitrobenzene [33], dimethyl oxalate [34], anthraquinone [35] or carbon oxides [36], its role has been limited to act as a part of a support ( $\mathrm{Pd} / \mathrm{Mg}$-La mixed oxide [32]) or as a promoter of $\mathrm{NiB}$ [33, 35] and $\mathrm{Ni}$ [36], as well as $\mathrm{Cu}$ [34]. In addition, only few methods are mentioned in the literature, where lanthanum is used in the hydrogenation of nitriles to amines, but it was also applied as a promoter of nickel only [37, 38]. Accordingly, to our best knowledge, there are no examples concerning the hydrogenation activity of lanthanum itself.

Our research group has efficiently used various supported heterogeneous catalysts in organic reactions $[39,40]$. For example a nickel on magnesium-lanthanum mixed oxide catalyst has recently been applied in the Kumada reaction [41]. A Pd/MgLa mixed oxide or a $\mathrm{Pd} / \mathrm{MgAl}$ mixed oxide catalyst was used in the catalytic transfer hydrogenation of cinnamic acid derivatives and hydrogenolysis of aromatic halides in ionic liquids [42].

In continuation of our interest, various metal oxide $(\mathrm{MgO})$ and mixed oxide $\left(\mathrm{MgO}-\mathrm{Al}_{2} \mathrm{O}_{3}\right)$ supported base metal ( $\mathrm{Ni}$ and $\mathrm{La}$ ) catalysts were prepared. The catalysts were characterized by BET, ICP-OES, SEM and EDS technique. The activity of the catalysts was tested in the heterogeneous catalytic hydrogenation of benzonitrile.

\section{Experimental}

\section{Materials}

The catalyst precursors (magnesium ethoxide, aluminium-tri-sec-butoxide), as well as $\mathrm{Ni}\left(\mathrm{NO}_{3}\right)_{2} \cdot 6 \mathrm{H}_{2} \mathrm{O}, \mathrm{La}\left(\mathrm{NO}_{3}\right)_{3} \cdot 6 \mathrm{H}_{2} \mathrm{O}$ and oxalic acid $(99 \%)$ were purchased from Merck KGaA, Darmstadt, Germany. 
Benzonitrile (99\%), benzyl cyanide (99\%), cinnamonitrile (98\%) and adiponitrile (99\%) were supplied from Merck-Schuchardt (Hohenbrunn, Germany). Methanol (p.a.) and ethanol (p.a.) were also purchased from Merck KGaA (Darmstadt, Germany).

\section{Catalyst preparation}

\section{Preparation of $\mathrm{MgO}$ with sol-gel method}

For the preparation of $\mathrm{MgO}$, magnesium ethoxide (15.4 g, $0.1346 \mathrm{~mol}$ ) in ethanol $(134 \mathrm{~mL})$ was stirred at reflux for $15 \mathrm{~min}$. Next, oxalic acid $(1.0 \mathrm{~g})$ dissolved in water $(5 \mathrm{~mL})$ was added to the reaction mixture to obtain a $\mathrm{pH}$ of 5 . The mixture was stirred at reflux for $2.5 \mathrm{~h}$. Then, water $(162 \mathrm{~mL})$ was added and the mixture was stirred at reflux for another $15 \mathrm{~min}$. Then it was dried at $80{ }^{\circ} \mathrm{C}$ overnight and continued to dry at $120^{\circ} \mathrm{C}$ for $8 \mathrm{~h}$. Finally, the dried mixture was calcined under air with the following temperature profile: at $5{ }^{\circ} \mathrm{C} / \mathrm{min}$ to $250{ }^{\circ} \mathrm{C}, 250{ }^{\circ} \mathrm{C}$ hold for $1 \mathrm{~h}$, at $5{ }^{\circ} \mathrm{C} / \mathrm{min}$ to $500-550{ }^{\circ} \mathrm{C}, 550{ }^{\circ} \mathrm{C}$ hold for $3 \mathrm{~h}$, then cooling at $10^{\circ} \mathrm{C} / \mathrm{min}$ to $30{ }^{\circ} \mathrm{C}$.

\section{Preparation of the $\mathrm{MgO}-\mathrm{Al}_{2} \mathrm{O}_{3}$ mixed oxide with sol-gel method}

For the preparation of $\mathrm{MgO}-\mathrm{Al}_{2} \mathrm{O}_{3}$, magnesium ethoxide (15.4 g, $0.1346 \mathrm{~mol}$ ) in ethanol $(134 \mathrm{~mL})$ was stirred at reflux for $15 \mathrm{~min}$. Next, oxalic acid $(1.0 \mathrm{~g})$ dissolved in water $(5 \mathrm{~mL})$ was added to the reaction mixture to obtain a $\mathrm{pH}$ of 5. The mixture was stirred at reflux for $2.5 \mathrm{~h}$. Then, aluminium-tri-sec-butoxide $(0.08978 \mathrm{~mol})$ and water $(162 \mathrm{~mL})$ were added, and the mixture was stirred at reflux for another $15 \mathrm{~min}$. Then, it was dried at $80{ }^{\circ} \mathrm{C}$ overnight and continued to dry at $120^{\circ} \mathrm{C}$ for $8 \mathrm{~h}$. Finally, the dried mixture was calcined under air with the following temperature profile: $5^{\circ} \mathrm{C} / \mathrm{min}$ to $250{ }^{\circ} \mathrm{C}, 250{ }^{\circ} \mathrm{C}$ hold for $1 \mathrm{~h}, 5{ }^{\circ} \mathrm{C} / \mathrm{min}$ to $500-550{ }^{\circ} \mathrm{C}, 550{ }^{\circ} \mathrm{C}$ hold for $3 \mathrm{~h}$, then cooling $10{ }^{\circ} \mathrm{C} / \mathrm{min}$ to $30^{\circ} \mathrm{C}$.

\section{Preparation of the monometallic catalysts with wet impregnation}

To prepare the monometallic catalysts $1.0 \mathrm{~g}$ of powdered $\mathrm{MgO}$ or $\mathrm{MgO}-\mathrm{Al}_{2} \mathrm{O}_{3}$ and $1.0 \mathrm{mmol}$ of the corresponding metal precursor $\left[\mathrm{Ni}\left(\mathrm{NO}_{3}\right)_{2} \cdot 6 \mathrm{H}_{2} \mathrm{O}\right.$ or $\mathrm{La}\left(\mathrm{NO}_{3}\right)_{3} \cdot 6 \mathrm{H}_{2} \mathrm{O}$ ] was stirred in $30 \mathrm{~mL}$ of deionized water at room temperature for $12 \mathrm{~h}$. Then it was dried at $120^{\circ} \mathrm{C}$ for $24 \mathrm{~h}$ and calcined with the following temperature profile: $5{ }^{\circ} \mathrm{C} / \mathrm{min}$ to $500{ }^{\circ} \mathrm{C}, 500{ }^{\circ} \mathrm{C}$ hold for $2 \mathrm{~h}$, then cooling $10{ }^{\circ} \mathrm{C} /$ min to $30{ }^{\circ} \mathrm{C}$. Then the catalyst was reduced with a $60 \mathrm{~mL} / \mathrm{min}_{2}$ flow using the following temperature profile: $5^{\circ} \mathrm{C} / \mathrm{min}$ to $700{ }^{\circ} \mathrm{C}, 700{ }^{\circ} \mathrm{C}$ hold for $4 \mathrm{~h}$, then cooling $10^{\circ} \mathrm{C} / \mathrm{min}$ to $30^{\circ} \mathrm{C}$. 


\section{Preparation of the bimetallic catalyst with successive impregnation}

For the preparation of the bimetallic catalyst the previously prepared La/ $\mathrm{MgO}-\mathrm{Al}_{2} \mathrm{O}_{3}$ catalyst was stirred with $\mathrm{Ni}\left(\mathrm{NO}_{3}\right)_{2} \cdot 6 \mathrm{H}_{2} \mathrm{O}$ as described above. The thermal treatments were also the same as mentioned afore.

\section{Typical procedure for the hydrogenation reactions}

The hydrogenation reactions were carried out in a $250 \mathrm{~mL}$ stainless steel autoclave (Technoclave, Budapest, Hungary) equipped with a magnetic stirrer (stirring speed: $1100 \mathrm{rpm}$ ), and electric heating system, at 10 bar and $100-130{ }^{\circ} \mathrm{C}$. The reactor containing nitrile $(2.0 \mathrm{~g})$, supported $\mathrm{Ni}$ or La catalyst $(0.2 \mathrm{~g})$ and methanol $(50 \mathrm{~mL})$ was flushed with nitrogen and hydrogen, then charged with hydrogen to the specified pressure and heated up to the given temperature. After finishing the hydrogen uptake, the catalyst was filtered off and the filtrate was evaporated under vacuum. The products were isolated in $96-99 \%$ and analysed by GC-MS.

The MS data of the starting materials and the products are the following: $\mathrm{BN}$ (see Figs. 4, 5, 6 and 7 for the abbreviations) $\mathrm{m} / z$ (rel\%) 103 (100), 76 (38), 50 (18); BA $m / z$ (rel\%) 106 (100), 91 (12), 79 (40), 51 (38), 30 (85); DBA $m / z$ (rel\%) 196 (10), 120 (11), 106 (57), 91 (100), 65 (17), 51 (8); BC m/z (rel\%) 117 (100), 90 (39), 77 (10), 63 (13), 51 (19); PEA 121 (23), 103 (11), 91 (100), 77 (20), 65 (90), 51 (72); BPEA m/z (rel\%) 134 (100), 105 (60), 91 (11), 77 (11), 65 (11), 42 (11); CN m/z (rel\%) 129 (100), 102 (44), 76 (13), 63 (10), 51 (17); PPN m/z (rel\%) 131 (30), 91 (100), 77 (4), 65 (10), 51 (6); BPPA m/z (rel\%) 253 (18), 148 (100), 117 (16), 105 (7), 91 (99), 77 (10), 65 (12), 56 (11); AN m/z (rel\%) 107 (2), 80 (4), 68 (90), 54 (100); ICN m/z (rel\%) 109 (19), 100 (95), 86 (28), 73 (78), 68 (76), 54 (100); BACN m/z (rel\%) 207 (1), 165 (12), 151 (16), 123 (100), 96 (43) 84 (36), 70 (25), 56 (60). These analytical results are in accordance with the literature data [43].

GC-MS analyses were performed by an Agilent 7890A GC-system (7683 autosampler and 7683B injector) connected to an Agilent 5975C mass spectrometer using a Restek Rxi®-5Sil MS capillary column $(15 \mathrm{~m} \times 0.25 \mathrm{~mm}$ ID, $0.25 \mu \mathrm{m}$ film). The temperature program was the following: $45^{\circ} \mathrm{C}(1 \mathrm{~min})$ to $300{ }^{\circ} \mathrm{C}$ at $50{ }^{\circ} \mathrm{C} / \mathrm{min}$, hold $1 \mathrm{~min}$ for $\mathrm{BN}, \mathrm{BC}$ and $\mathrm{AN}$, as well as $70{ }^{\circ} \mathrm{C}(1 \mathrm{~min})$ to $300{ }^{\circ} \mathrm{C}$ at $33{ }^{\circ} \mathrm{C} / \mathrm{min}$, hold $2 \mathrm{~min}$ for $\mathrm{CN}$.

\section{Catalyst characterization}

Inductively coupled plasma optical emission spectrometry (ICP-OES) analysis was carried out on a Perkin-Elmer Optima 2000DV to determine the metal content on the support.

The specific surface area of the catalysts was measured by nitrogen adsorption and desorption at $-196{ }^{\circ} \mathrm{C}$ with BET (Brunauer-Emmett-Teller) surface analyser 
(Micromeritics Model TRISTAR 3000) using BET-BJH (Barrett-Joyner-Halenda) method after drying each material in anaerobic chamber for $12 \mathrm{~h}$.

The structure and morphology of the catalysts were investigated with a JEOL JSM-5500LV scanning electron microscope. Samples for SEM analysis were placed on a copper grid coated with carbon film then coated with gold nano-layer prior to analysis. Electron beam energy of $20 \mathrm{kV}$ was used in every case.

The elemental analysis was carried out with energy dispersive spectroscopy/ energy dispersive X-ray analysis (EDS/EDAX with $\mathrm{Si}(\mathrm{Li})$ detector) coupled with JEOL JSM-5500LV SEM applying $20 \mathrm{kV}$ accelerating voltage and sampling time of $60 \mathrm{~s}$. The element composition of the samples was calculated from five parallel measurements.

\section{Results and discussion}

\section{Catalyst characterization}

An ICP-OES analysis of the catalysts was carried out to determine the real metal content. The metal content on the surface of the catalysts was also examined by EDS measurements. Based on the ICP-OES data, it can be concluded that the metal contents of the catalysts are in accordance with the theoretical values. The EDS results show that the metallic particles can unambiguously be detected on the surface of the catalysts (Table 1).

Fig. 1 shows the SEM images of the prepared catalysts. In case of the $\mathrm{MgO}$-supported materials higher aggregation of the particles can be seen. The $\mathrm{MgO}-\mathrm{Al}_{2} \mathrm{O}_{3}$ supported materials have a less compact structure. This more porous structure may result the higher specific surface area observed (Table 1).

In Fig. 2, the particle size distributions of the different catalysts are shown. In all cases most of the particles are between 1 and $30 \mu \mathrm{m}$. The average particle size is around $18-19 \mu \mathrm{m}$, except for the $\mathrm{La} / \mathrm{MgO}$, where the average particle size is $12 \mu \mathrm{m}$. Generally, the particles are between 1 and $50 \mu \mathrm{m}$, but a few particles with a particle size of up to $85 \mu \mathrm{m}$ can be observed.

Fig. 3 shows the BET isotherms of the prepared catalysts. According to Brunauer, Emmett and Teller the $\mathrm{S}$-shaped isotherms for $\mathrm{Ni} / \mathrm{MgO}$ and $\mathrm{La} / \mathrm{MgO}$ are Type II

Table 1 Metal content and BET surface area of the catalysts

\begin{tabular}{|c|c|c|c|c|c|c|c|c|}
\hline \multirow[t]{2}{*}{ Entry } & \multirow[t]{2}{*}{ Catalysts } & \multicolumn{2}{|c|}{$\begin{array}{l}\text { Theoretical } \\
\text { values }\end{array}$} & \multicolumn{2}{|c|}{$\begin{array}{l}\text { Measured values } \\
\text { (ICP) }\end{array}$} & \multicolumn{2}{|c|}{$\begin{array}{l}\text { Measured values } \\
\text { (EDS) }\end{array}$} & \multirow[t]{2}{*}{$\begin{array}{l}\text { BET surface } \\
\text { area }\left(\mathrm{m}^{2} \mathrm{~g}^{-1}\right)\end{array}$} \\
\hline & & $\begin{array}{l}\mathrm{Ni} \\
(\mathrm{wt} \%)\end{array}$ & $\begin{array}{l}\mathrm{La} \\
(\mathrm{wt} \%)\end{array}$ & $\begin{array}{l}\mathrm{Ni} \\
(\mathrm{wt} \%)\end{array}$ & $\begin{array}{l}\mathrm{La} \\
(\mathrm{wt} \%)\end{array}$ & $\begin{array}{l}\mathrm{Ni} \\
(\mathrm{wt} \%)\end{array}$ & $\begin{array}{l}\mathrm{La} \\
(\mathrm{wt} \%)\end{array}$ & \\
\hline 1 & $\mathrm{Ni} / \mathrm{MgO}$ & 5.53 & - & 5.3 & - & 7.37 & - & 51.8 \\
\hline 2 & $\mathrm{La} / \mathrm{MgO}$ & - & 12.19 & - & 12.2 & - & 14.43 & 33.7 \\
\hline 3 & $\mathrm{Ni} / \mathrm{MgO}-\mathrm{Al}_{2} \mathrm{O}_{3}$ & 5.53 & - & 4.9 & - & 6.56 & - & 196.7 \\
\hline 4 & $\mathrm{Ni}-\mathrm{La} / \mathrm{MgO}-\mathrm{Al}_{2} \mathrm{O}_{3}$ & 5.53 & 12.19 & 5.0 & 10.9 & 8.22 & 12.70 & 160.9 \\
\hline
\end{tabular}



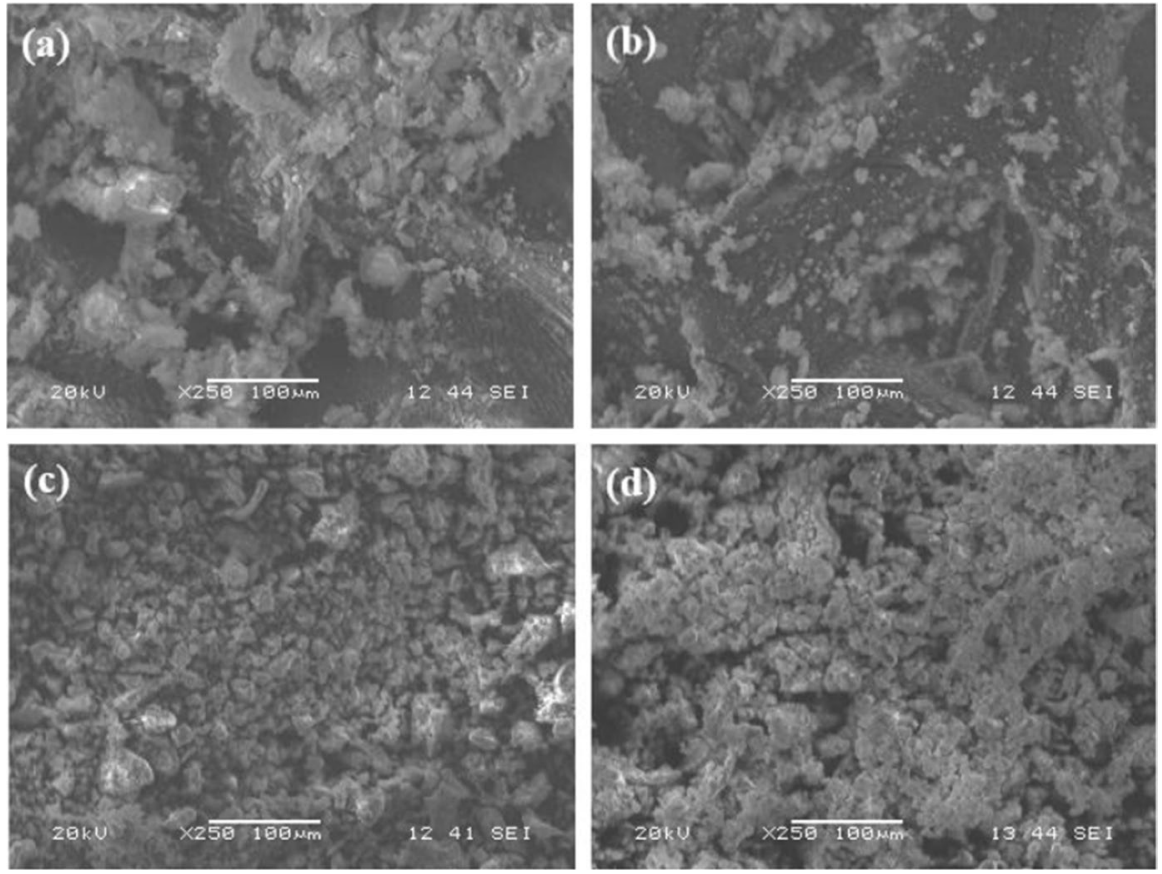

Fig. 1 SEM images of the catalysts: a Ni/MgO, b La/MgO, $\mathbf{c} \mathrm{Ni} / \mathrm{MgO}-\mathrm{Al}_{2} \mathrm{O}_{3}, \mathbf{d ~ N i}-\mathrm{La} / \mathrm{MgO}-\mathrm{Al}_{2} \mathrm{O}_{3}$

$\mathrm{Ni} / \mathrm{MgO}$

Particles between 1-90 $\mu \mathrm{m}$

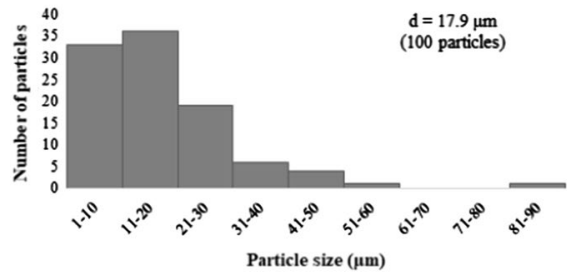

$\mathrm{Ni} / \mathrm{MgO}-\mathrm{Al}_{2} \mathrm{O}_{3}$

Particles between 1-90 $\mu \mathrm{m}$

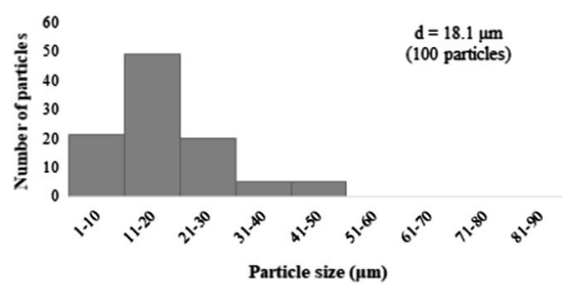

Fig. 2 Particle size distribution of the catalysts
$\mathrm{La} / \mathrm{MgO}$

Particles between 1-90 $\mu \mathrm{m}$

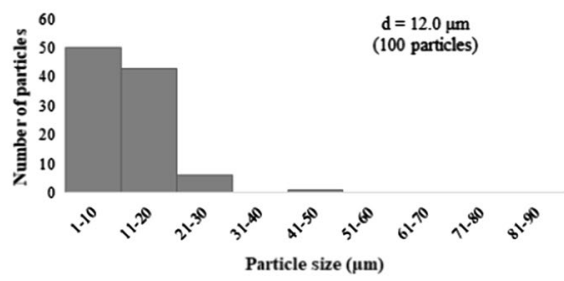

$\mathrm{Ni}-\mathrm{La} / \mathrm{MgO}-\mathrm{Al}_{2} \mathrm{O}_{3}$ Particles between 1-90 $\mu \mathrm{m}$

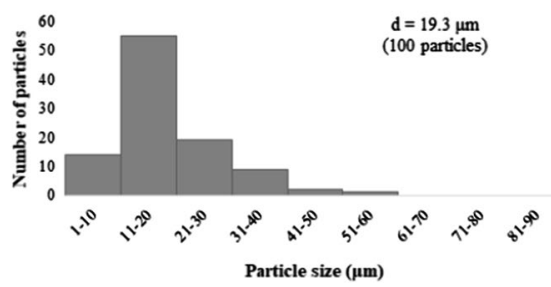



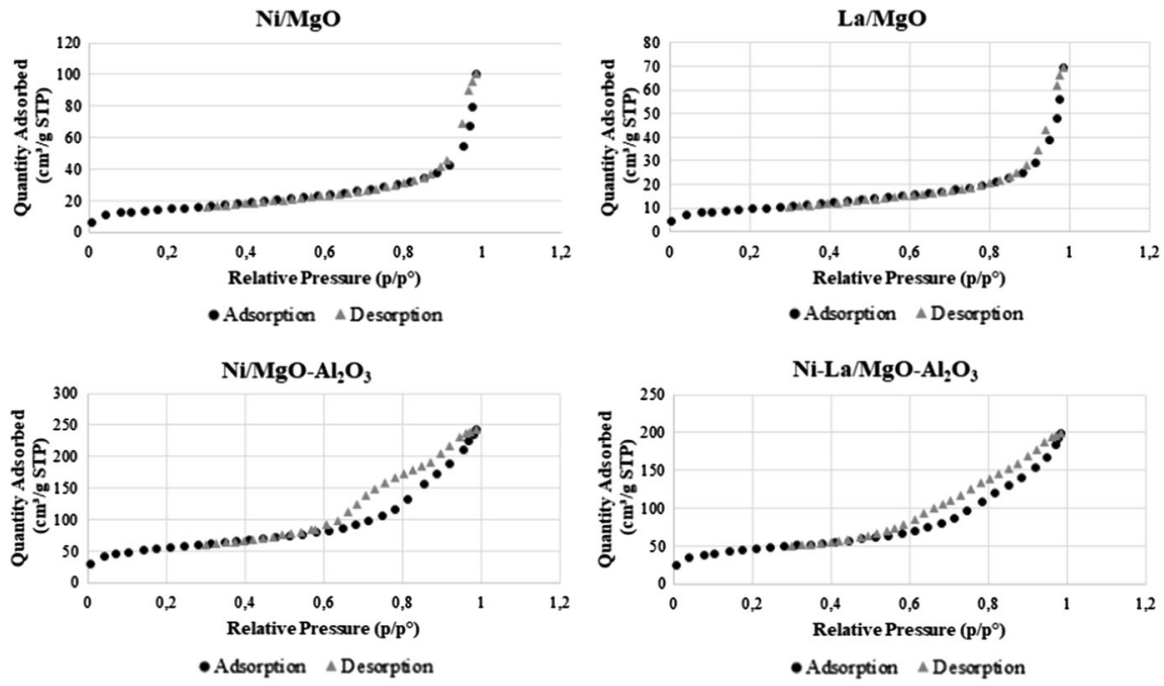

Fig. 3 BET isotherms of the catalysts<smiles>N#Cc1ccccc1</smiles>

BN
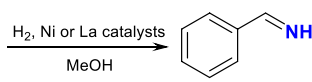

$\underset{\mathrm{MeOH}}{\stackrel{\mathrm{H}_{2}, \mathrm{Ni} \text { or La catalysts }}{\longrightarrow}}$

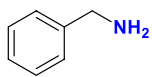

BI

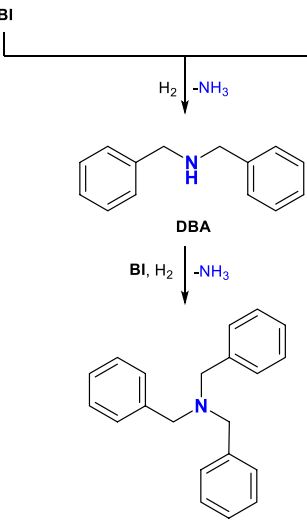

BA

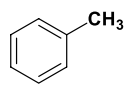

$\mathrm{T}$

TBA

Fig. 4 Nickel-lanthanum-catalysed hydrogenation of benzonitrile (BN)—reaction pathway

BET isotherms, meaning that the low pressure portion of the isotherm is concave to the pressure axis, the higher pressure region convex and the intermediate region approximately linear [44, 45]. At the beginning by lower pressures the micropores are filled with nitrogen gas. At the knee of the isotherm the monolayer formation begins. After the complete monolayer coverage, a multilayer formation occurs. Lastly, at high pressures capillary condensation takes place. The other two isotherms 
Table 2 Hydrogenation of BN over magnesia(-alumina) supported Ni or La catalysts

\begin{tabular}{llllllll}
\hline Entry & Catalyst & $\begin{array}{l}\text { Temperature } \\
\left({ }^{\circ} \mathrm{C}\right)\end{array}$ & $\begin{array}{l}\text { Reaction } \\
\text { time }(\mathrm{h})\end{array}$ & $\begin{array}{l}\text { Conversion } \\
(\%)\end{array}$ & $\begin{array}{l}\text { Product } \\
\text { Isolated } \\
\text { yield } \\
(\%)\end{array}$ & $\begin{array}{l}\text { BA-content }{ }^{\mathrm{a}} \\
(\%)\end{array}$ & $\begin{array}{l}\text { Selectivity } \\
\text { to BA }(\%)\end{array}$ \\
\hline 1 & $\mathrm{Ni} / \mathrm{MgO}$ & $30-130$ & 8.0 & 100 & 73 & 68.1 & 50 \\
2 & $\mathrm{Ni} / \mathrm{MgO}$ & 100 & 5.0 & 100 & 96 & 44.8 & 43 \\
3 & $\mathrm{La} / \mathrm{MgO}$ & 100 & 5.0 & 98 & 96 & 47.9 & 47 \\
4 & $\mathrm{Ni} / \mathrm{MgO}-$ & 100 & 5.0 & 100 & 96 & 53.5 & 52 \\
5 & $\begin{array}{l}\mathrm{Al} \mathrm{O}_{3} \\
\mathrm{Ni}-\mathrm{La} / \mathrm{MgO}-\end{array}$ & 100 & 5.0 & 100 & 95 & 52.6 & 50 \\
\hline
\end{tabular}

Conditions: $2.0 \mathrm{~g}$ benzonitrile, $0.1 \mathrm{~g} / \mathrm{g}^{-1}$ catalyst/substrate ratio, $50 \mathrm{~mL}$ methanol, $10 \mathrm{bar}$

aThe main by-product was dibenzylamine (DBA) and no formation of tribenzylamine (TBA) was observed

for $\mathrm{Ni} / \mathrm{MgO}-\mathrm{Al}_{2} \mathrm{O}_{3}$ and $\mathrm{Ni}-\mathrm{La} / \mathrm{MgO}-\mathrm{Al}_{2} \mathrm{O}_{3}$ are Type IV BET isotherms with a hysteresis loop. In these cases capillary condensation occurs in the mesopores.

\section{Catalytic test in the hydrogenation of benzonitrile}

The four supported metal catalysts, $\mathrm{Ni} / \mathrm{MgO}, \mathrm{La} / \mathrm{MgO}, \mathrm{Ni} / \mathrm{MgO}-\mathrm{Al}_{2} \mathrm{O}_{3}$ and $\mathrm{Ni}-\mathrm{La} / \mathrm{MgO}-\mathrm{Al}_{2} \mathrm{O}_{3}$ were tested in the hydrogenation of benzonitrile $(\mathrm{BN})$ at different temperatures in methanol, without any additive (Fig. 4). First the activity and selectivity of the different catalysts were tested. The results are summarized in Table 2.

Table 3 Hydrogenation of nitriles over $\mathrm{La} / \mathrm{MgO}$

\begin{tabular}{|c|c|c|c|c|c|}
\hline \multirow[t]{2}{*}{ Entry } & \multirow[t]{2}{*}{ Substrate } & \multirow[t]{2}{*}{ Conversion (\%) } & \multicolumn{2}{|l|}{ Product } & \multirow{2}{*}{$\begin{array}{l}\text { Selectivity to } \\
\text { primary amine } \\
(\%)\end{array}$} \\
\hline & & & $\begin{array}{l}\text { Isolated } \\
\text { yield (\%) }\end{array}$ & $\begin{array}{l}\text { Primary amine } \\
\text { content }(\%)\end{array}$ & \\
\hline 1 & Benzyl cyanide & 49 & 97 & $6.2^{\mathrm{a}}$ & 13 \\
\hline 2 & Cinnamonitrile & $\begin{array}{l}100(\mathrm{C}=\mathrm{C}) \\
22(\mathrm{CN})\end{array}$ & 97 & $10.6^{\mathrm{b}}$ & 46 \\
\hline 3 & Adiponitrile & 12 & 99 & $0^{\mathrm{c}}$ & 0 \\
\hline
\end{tabular}

Conditions: $2.0 \mathrm{~g}$ substrate, $0.1 \mathrm{~g} \cdot \mathrm{g}^{-1}$ catalyst/substrate ratio, $50 \mathrm{~mL}$ methanol, $10 \mathrm{bar}, 100{ }^{\circ} \mathrm{C}$, reaction time: $5 \mathrm{~h}$

${ }^{\mathrm{a}}$ The main by-product was bis(2-phenylethyl)amine (BFEA) and no formation of tris(2-phenylethyl) amine (TFEA) was observed

${ }^{\mathrm{b}}$ The main by-product was bis(2-phenylpropyl)amine (BFPA) and no formation of tris(2-phenylpropyl) amine (TFPA) was observed

${ }^{\mathrm{c}}$ The main product was 6-iminocapronitrile (ICN) and no formation of 6-aminocapronitrile (ACN) or 1,6-hexamethylenediamine (primary amines) was observed 


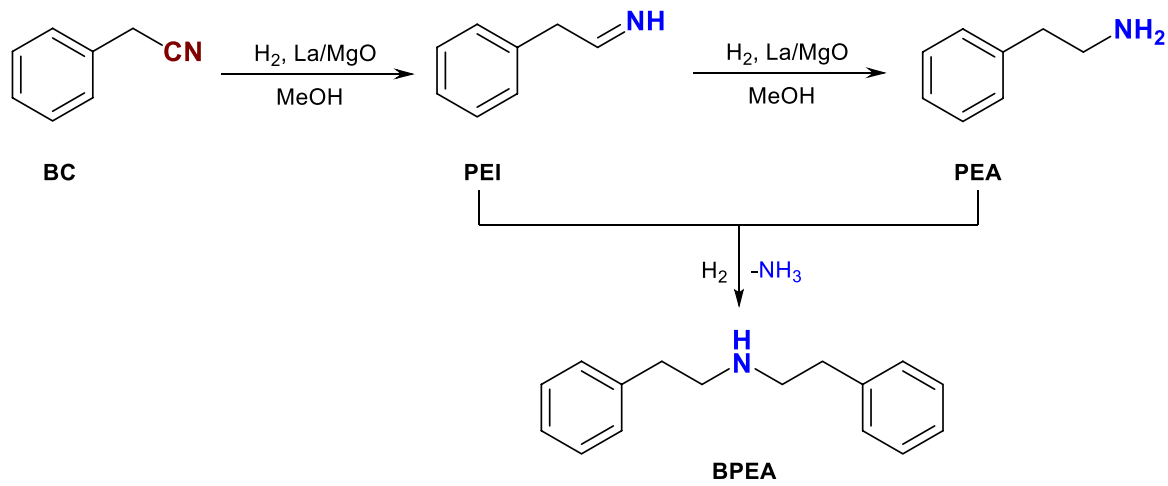

Fig. 5 Hydrogenation of benzyl cyanide (BC) over $\mathrm{La} / \mathrm{MgO}$
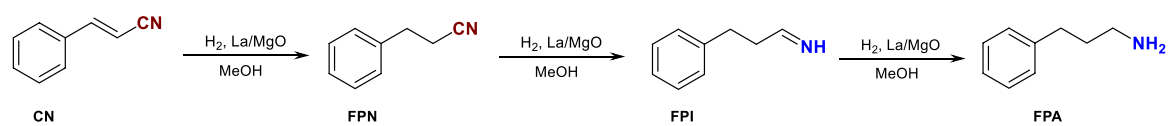

FPI

FPA

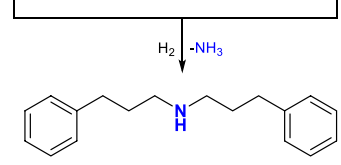

BFPA

Fig. 6 Hydrogenation of cinnamonitrile $(\mathrm{CN})$ over $\mathrm{La} / \mathrm{MgO}$

As seen, all catalysts were active in the hydrogenation of benzonitrile. It was found that it is expedient to perform the $\mathrm{Ni} / \mathrm{MgO}$-catalysed reduction at $100{ }^{\circ} \mathrm{C}$ and 10 bar pressure, because at higher temperature $\left(130{ }^{\circ} \mathrm{C}\right)$ the isolated yield was only $73 \%$, due to a hydrogenolytic side reaction resulting in the formation of toluene (T). In the latter case, the BA-content was the highest $(68.1 \%)$ and the selectivity to BA was $50 \%$. Whereas, complete conversions, excellent yields (95-96\%), as well as very similar primary amine selectivity (43-52\%) were achieved with all catalysts at lower temperature $\left(100{ }^{\circ} \mathrm{C}\right)$.

Among these results the most interesting was the remarkable hydrogenation activity of lanthanum (entry 3 ). Thus, the scope of the reaction in the presence of the $\mathrm{La} / \mathrm{MgO}$ catalyst was extended to the hydrogenation of other nitriles, such as benzyl cyanide, cinnamonitrile (the homologues of $\mathrm{BN}$ ) and adiponitrile (dinitrile). The reaction was carried out under the same conditions as described above. The results are summarized in Table 3.

As seen, much lower conversion of the nitrile group was obtained as the aliphatic properties of the starting materials increased.

When benzyl cyanide (BC) was hydrogenated (Fig. 5) over $\mathrm{La} / \mathrm{MgO}$, the conversion was $49 \%$ and only $13 \%$ selectivity to 2 -phenylethylamine (PEA) was achieved and mainly the secondary amine, bis(2-phenylethyl)amine (BFEA) was formed with $87 \%$ selectivity. 


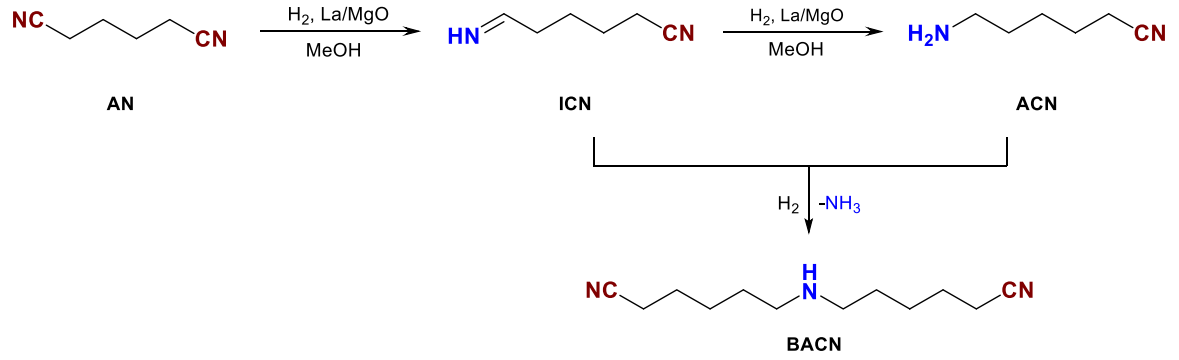

Fig. 7 Hydrogenation of adiponitrile (AN) over $\mathrm{La} / \mathrm{MgO}$

During the La-catalysed hydrogenation of cinnamonitrile (CN) (Fig. 6), the saturation of the $\mathrm{C}=\mathrm{C}$ double bond took place completely resulting in 3-phenylpropionitrile (FPN), but the conversion of the nitrile group was low $(22 \%)$. Whereas, the selectivity to 3-phenylpropylamine (FPA) was 46\%, and the by-product was the secondary amine [bis(3-phenylpropyl)amine (BFPA)] only with 54\% selectivity.

In the hydrogenation of adiponitrile ( $\mathrm{AN}$ ) over $\mathrm{La} / \mathrm{MgO}$ (Fig. 7), very low conversion was obtained (12\%), and only one nitrile group was reduced to 6-iminocapronitrile (ICN) with 75\% selectivity. In addition, a secondary amine [bis(6aminocapronitrile) (BACN)] was detected as a by-product, but no formation of 6-aminocapronitrile (ACN) or 1,6-hexamethylenediamine (primary amines) was observed.

\section{Conclusions}

$\mathrm{Ni}$ or $\mathrm{La}$ on $\mathrm{MgO}$ and $\mathrm{MgO}-\mathrm{Al}_{2} \mathrm{O}_{3}$ and $\mathrm{Ni}-\mathrm{La}$ on $\mathrm{MgO}-\mathrm{Al}_{2} \mathrm{O}_{3}$ catalysts have been prepared and characterized. The EDS measurements showed that the metal is located mostly on the surface of the supports. The activity of the catalysts was tested in the heterogeneous catalytic hydrogenation of benzonitrile in methanol without any additives. The $\mathrm{La} / \mathrm{MgO}$ catalyst was found to be very effective in the reaction, which is unprecedented in the literature. The reaction scope was broadened the hydrogenation of benzyl cyanide, cinnamonitrile and adiponitrile was studied over this $\mathrm{La} / \mathrm{MgO}$ catalyst. However, in these cases only a low amount of the desired primary amine could be identified in the reaction mixture. During the hydrogenation of cinnamonitrile the main product was 3-phenylpropionitrile instead of the 3-phenylpropylamine. In conclusion, the prepared supported base metal catalysts, especially the $\mathrm{La} / \mathrm{MgO}$, can be used in the hydrogenation of benzonitrile with $43-52 \%$ primary amine selectivity. 
Acknowledgements The research reported in this paper and carried out at BME has been supported by the NRDI Fund (TKP2020 NC, Grant No. BME-NC) based on the charter of bolster issued by the NRDI Office under the auspices of the Ministry for Innovation and Technology. The work was carried out within the framework of the Hungarian-French intergovernmental scientific and technological cooperation, project no. 2018-2.1.13-TÉT-FR-2018-00011. The authors thank Dr. Tibor Novák (Servier Research Institute, Hungary) for providing GC-MS measurements.

Funding Open access funding provided by Budapest University of Technology and Economics.

\section{Declarations}

Conflict of interest The authors declare that they have no conflict of interest.

Open Access This article is licensed under a Creative Commons Attribution 4.0 International License, which permits use, sharing, adaptation, distribution and reproduction in any medium or format, as long as you give appropriate credit to the original author(s) and the source, provide a link to the Creative Commons licence, and indicate if changes were made. The images or other third party material in this article are included in the article's Creative Commons licence, unless indicated otherwise in a credit line to the material. If material is not included in the article's Creative Commons licence and your intended use is not permitted by statutory regulation or exceeds the permitted use, you will need to obtain permission directly from the copyright holder. To view a copy of this licence, visit http://creativecommons.org/licen ses/by/4.0/.

\section{References}

1. Ertl G, Knözinger H, Schüth F, Weitkamp (2008) J handbook of heterogeneous catalysis, 2nd edn. Wiley, Weinheim

2. Roose P, Eller K, Henkes E, Rossbacher R, Höke H (1985) Ullmann's Encyclopedia of industrial chemistry, 7th edn. Wiley-VCH Verlag, Weinheim

3. Ippen (1968) H Index Pharmacorum. Thieme Verlag, Stuttgart

4. Heuer L (2006) Benzylamine in: Ullmann's Encyclopedia of Industrial Chemistry. Wiley-VCH Verlag $\mathrm{GmbH} \& \mathrm{Co}$ KGaA, Weinheim

5. Szőllősi G, Hanaoka T, Niwa S, Mizukami F, Bartók M (2005) J Catal 231:480-483

6. Rylander PN (1976) Catalytic hydrogenation over platinum metals. Academic Press, New York

7. Freifelder M (1971) Practical catalytic hydrogenation. Wiley, New York

8. Lévay K, Hegedűs L (2018) Period Polytech Chem Eng 62:476-488

9. Allgeier AM, Sengupta SK (2018). In: Jackson SD (ed) Hydrogenation: catalysts and processes. Walter de Gruyter, Berlin, pp 107-154

10. Lévay K, Hegedűs L (2019) Curr Org Chem 23:1881-1900

11. Hartung WH (1928) J Am Chem Soc 50:3370-3374

12. Miller E, Sprague JM, Kissinger CW, McBurney LF (1940) J Am Chem Soc 62:2099-2103

13. Schwartz MA, Zoda M, Vishnuvajjala B, Mami I (1976) J Org Chem 41:2502-2503

14. Carothers WH, Jones GA (1925) J Am Chem Soc 47:3051-3057

15. Overberger CG, Mulvaney JE (1959) J Am Chem Soc 81:4697-4701

16. Gould F, Johnson G, Ferris A (1960) J Org Chem 25:1658-1660

17. Huber W (1944) J Am Chem Soc 66:876-879

18. Freifelder M (1960) J Am Chem Soc 82:2386-2389

19. Greenfield H (1967) Ind Eng Chem Prod Res Dev 6:142-144

20. Bawane SP, Sawant SB (2004) Chem Eng J 103:13-19

21. Cao Y, Zhang H, Dong J, Ma Y, Sun H, Niu L, Lan X, Cao L, Bai G (2019) Mol Catal 475:110452

22. Cheng H, Meng X, Wu C, Shan X, Yu Y, Zhao F (2013) J Mol Catal A: Chem 379:72-79

23. Cao Y, Niu L, Wen X, Feng W, Huo L, Bai G (2016) J Catal 339:9-13

24. Takao T, Horikoshi S, Kawashima T, Asano S, Takahashi Y, Sawano A, Suzuki H (2018) Organometallics 37:1598-1614

25. Li T, Bergner I, Haque FN, Zimmer-De Iuliis N, Song D, Morris RH (2007) Organometallics 26:5940-5949 
26. Takemoto S, Kawamura H, Yamada Y, Okada T, Ono A, Yoshikawa E, Mizobe Y, Hidai M (2002) Organometallics 21:3897-3904

27 Bakker JJW, van der Neut AG, Kreutzer MT, Moulijn JA, Kapteijn F (2010) J Catal 274:176-191

28. Dai C, Zhu S, Wang X, Zhang C, Zhang W, Li Y, Ning C (2017) New J Chem 41:3758-3765

29. Hao Y, Li M, Cárdenas-Lizana F, Keane MA (2016) Catal Lett 146:109-116

30. Hegedűs L, Máthé T (2005) Appl Catal A Gen 296:209-215

31. McAllister MI, Boulho C, McMillan L, Gilpin LF, Brennan C, Lennon D (2019) Org Process Res Dev 23:977-989

32. Kantam ML, Kishore R, Yadav J, Sudhakar M, Venugopal A (2012) Adv Synth Catal 354:663-669

33. Liu YC, Chen YW (2006) Ind Eng Chem Res 45:2973-2980

34. Zheng X, Lin H, Zheng J, Duan X, Yuan Y (2013) ACS Catal 3:2738-2749

35. Hou Y (2004) Appl Catal A Gen 259:35-40

36. Znak L, Stołecki K, Zieliński J (2005) Catal Today 101:65-71

37. Lv Y, Hao F, Liu P, Xiong S, Luo H (2016) Reac Kinet Mech Cat 119:555-568

38. Lv Y, Hao F, Xiong S, Liu P, Luo H (2016) RSC Adv 6:60933-60939

39. Magyar Á, Juhász K, Hell Z (2021) Synthesis 53:279-295

40. Kiss Á, Németh J, Fodor A, Hell Z (2015) Period Polytech Chem Eng 59:72-81

41. Kiss Á, Hell Z, Bálint M (2010) Org Biomol Chem 8:331-335

42. Baán Z, Potor A, Cwik A, Hell Z, Keglevich G, Finta Z, Hermecz I (2007) Synth Commun 38:1601-1609

43. Wallace WE (2021) Mass Spectra in NIST Chemistry WebBook, NIST Standard Reference Database Number 69; P. J. Linstrom, W. G. Mallard, Eds.; National Institute of Standards and Technology, Gaithersburg, p. 20899

44. Brunauer S, Emmett PH, Teller E (1938) J Am Chem Soc 60:309-319

45. Brunauer S, Deming LS, Deming WE, Teller E (1940) J Am Chem Soc 62:1723-1732

Publisher's Note Springer Nature remains neutral with regard to jurisdictional claims in published maps and institutional affiliations. 